\title{
Insoluble Glucan Synthesis by Mutansucrase as a Determinant of the Cariogenicity of Streptococcus mutans
}

\author{
By D. G. WENHAM, ${ }^{1}$ R. M. DAVIES ${ }^{2}$ AND J. A. COLE \\ ${ }^{1}$ Department of Biochemistry, University of Birmingham, Birmingham B15 2TT, U.K. \\ ${ }^{2}$ Imperial Chemical Industries Ltd, Pharmaceuticals Division, Mereside, Alderley Park, \\ Macclesfield SK10 4TG, U.K.
}

(Received 2 March 1981)

\begin{abstract}
Five strains of Streptococcus mutans were grown in continuous culture with either a limited supply or an excess of glucose. Proteins secreted into the extracellular fluid by strains C67-1, 3209 and $\mathrm{K} 1$ rapidly catalysed the synthesis of insoluble glucan from sucrose (mutansucrase activity). The culture fluid from strains Ingbritt or C67-25 catalysed the synthesis of soluble glucan (dextransucrase activity) and fructan, but little or no mutansucrase activity was detected. The strains which secreted active mutansucrase readily colonized a smooth hard surface during growth in batch culture and were more cariogenic in pathogen-free rats than those which secreted little mutansucrase activity. There was no similar correlation between fructosyltransferase, dextransucrase or total glucosyltransferase activity and either adherence or cariogenicity. We conclude that the ability to catalyse insoluble glucan synthesis is a major determinant of the cariogenicity of $S$. mutans strains.
\end{abstract}

\section{INTRODUCTION}

The synthesis of extracellular polysaccharides from sucrose is believed to be a major determinant in the induction of tooth decay by Streptococcus mutans. Evidence for this includes the demonstration that mutants which produce more polysaccharide than the wild type are more adherent (Schachtele et al., 1975) and those which produce less are less cariogenic (De Stoppelaar et al., 1971; Tanzer et al., 1974; Koga \& Inoue, 1978). Furthermore, experimental animals which had been injected with enzymes involved in polysaccharide synthesis became less susceptible to caries induced by $S$. mutans (Smith et al., 1979). Also, fewer lesions developed when plaque was treated with glucanases (Guggenheim et al., 1972, 1980). Apparently conflicting results include the isolation of a non-cariogenic mutant which forms normal quantities of polysaccharide that is unable to bind to the bacterial surface (Freedman \& Tanzer, 1974). It was suggested that the binding of glucans to surface receptors is more important than the quantity of glucan formed in determining the cariogenicity of a particular strain. Furthermore, Dummer \& Green (1980) recently reported that there was no correlation between the extracellular glucosyltransferase activity secreted by a strain and its cariogenicity.

At least three different types of polysaccharide are synthesized from sucrose by extracellular proteins of $S$. mutans. They are a water-soluble glucan ('dextran', formed by dextransucrase) in which 1,6- $\alpha$ glycosidic bonds predominate, an insoluble glucan ('mutan', formed by mutansucrase) with a majority of $1,3-\alpha$ and a minority of $1,6-\alpha$ glycosidic bonds and a fructan with either 2,1- $\beta$ or 2,6- $\beta$ linkages (formed by fructosyltransferase) (Baird et al., 1973; Ellwood et al., 1976). The most significant polysaccharide in the disease process is believed to be the insoluble glucan which both binds bacteria to the tooth surface and forms a permeability barrier within which acidic fermentation products accumulate and 
demineralization occurs (Hojo et al., 1976). Although qualitative differences between the amounts of glucan or fructan formed by different strains have been reported, few authors have attempted to determine the relative quantities of mutan and dextran formed by strains of differing cariogenicity. Only Wenham et al. (1979) have reported rates of synthesis of dextransucrase, mutansucrase and fructosyltransferase during growth of $S$. mutans strains under rigorously controlled conditions. The aim of the work to be described was to determine whether there is a correlation between the mutansucrase activity secreted by a particular strain (rather than the total rate of extracellular polysaccharide or glucan synthesis) and its cariogenicity or ability to colonize a smooth surface.

\section{METHODS}

Organisms, media and culture conditions. Streptococcus mutans strains Ingbritt, C67-1 and C67-25 (all serotype $c$ ) were obtained as freeze-dried cultures from J. M. Hardie, The London Hospital Medical College, London E1. These strains were used because Ingbritt was originally isolated as a cariogenic strain from a human (Krasse, 1966), and C67-25 is a non-cariogenic derivative of the cariogenic C67-1 which differs from its parent only in its inability to form insoluble glucan (De Stoppelaar et al., 1971, 1973; Wenham, 1979). Strain K1 (serotype $d$ ) was obtained as colonies on nutrient agar from R. R. B. Russell, Royal College of Surgeons of England, Downe, Kent. Strains 3209 and 3450 (both serotype $c$ ) were isolated from the carious dentine of a permanent tooth and a deciduous tooth, respectively. They were received as colonies on blood agar from D. A. Sidaway, The Dental Hospital, St Chad's Queensway, Birmingham. Strain D282 (serotype $c$ ) was obtained as a freeze-dried culture from ICI Pharmaceuticals Division, Alderley Edge, Cheshire.

Pure cultures of each strain fermented mannitol, sorbitol and raffinose, were catalase-negative and formed a characteristic range of colony types on mitis-salivarius agar (Difco) and horse blood agar (Shklair \& Keene, 1974). Stock cultures were maintained on horse blood agar and were subcultured every $14 \mathrm{~d}$. Fresh cultures were generated from freeze-dried stocks every 3 months. To ensure that the origin of each strain was known, fresh cultures were always used to prepare inocula for continuous cultures, for colonization studies and for cariogenicity experiments.

Bacteria were grown in continuous culture as described by Wenham et al. (1979). The $\mathrm{pH}$, temperature and dilution rate were $6.6 \pm 0.1,37^{\circ} \mathrm{C}$ and $0.12 \mathrm{~h}^{-1}$, respectively. The volume was $840 \mathrm{ml}$ in a $1.5 \mathrm{l}$ fermentation vessel and $\mathrm{N}_{2} / \mathrm{CO}_{2}\left(95: 5\right.$, by vol.) was passed through the culture at $500 \mathrm{ml} \mathrm{h}^{-1}$. The growth rate was within the range estimated for streptococci in the mouth (as quoted by Hamilton et al., 1979). Bacteria in the deepest layers of dental plaque in contact with the tooth enamel are believed to be carbon-limited, but excess fermentable carbohydrate is supplied to bacteria in surface layers during feeding (Carlsson \& Griffith, 1974; Geddes, 1975; van der Hoeven, 1976). Enzyme activities were therefore determined for steady-state cultures (after at least five culture volumes had passed through the fermenter and when the cell yield was constant) in which glucose was either the growth-limiting nutrient or available in excess $\left(6\right.$ or $36 \mathrm{~g} \mathrm{l}^{-1}$, respectively). In the latter case, growth was limited by one or more organic nitrogen compounds (other than cysteine) in yeast extract, Casamino acids or peptone. Hamilton et al. (1979) have presented evidence that growth might be limited by the supply of arginine and asparagine.

Colonization studies. The method was based on that described by McCabe et al. (1967). Each strain was inoculated into $5 \mathrm{ml}$ brain heart infusion broth (Oxoid) supplemented with $5 \%(\mathrm{w} / \mathrm{v})$ of either glucose or sucrose in a $10 \times 1 \mathrm{~cm}$ test tube. A sterile nichrome wire was inserted into each tube and supported by a rubber bung. Tubes were agitated gently for $24 \mathrm{~h}$ at $37^{\circ} \mathrm{C}$ and each wire was then transferred to fresh broth for a further $24 \mathrm{~h}$. The extent of bacterial adherence and colonization was recorded photographically.

Enzyme assays and chemical determinations. Extracellular glucosyl- and fructosyltransferase assays were exactly as described by Wenham et al. (1979). Briefly, $1.0 \mathrm{ml}$ of culture supernatant and sucrose were incubated at $37^{\circ} \mathrm{C}$ in multiple sets of tubes for 0.5 to $2.0 \mathrm{~h}$ with or without $60 \mu \mathrm{g}$ dextran ml-1 (mol. wt range 60000 to $90000 ; \mathrm{BDH}$ ). Insoluble glucan was sedimented by centrifugation, washed three times with water, dissolved in 1.0 $\mathrm{M}-\mathrm{NaOH}$ and the quantities of ketohexose and total polysaccharide in the polymer were determined. The total polysaccharide (mutan, soluble glucan and fructan) formed in some of these tubes was precipitated at $4{ }^{\circ} \mathrm{C}$ with $80 \%(\mathrm{v} / \mathrm{v})$ methanol. After three cycles of centrifugation, redissolution in $1 \mathrm{ml}$ water and precipitation at $4{ }^{\circ} \mathrm{C}$ with $80 \%(\mathrm{v} / \mathrm{v})$ methanol, the pellet was dissolved in $1.0 \mathrm{M}-\mathrm{NaOH}$ and the quantities of fructan and total polysaccharide were determined. Thus, the mutansucrase and fructosyltransferase activities were determined by direct assay and dextransucrase activity was calculated from the formula given by Wenham et al. (1979).

Cell-associated enzyme activities were assayed by incubating $1 \mathrm{ml}$ of a washed cell suspension (resuspended in acetate buffer to the same turbidity as in the original culture) with sucrose and precipitating the polysaccharides formed with methanol. Other details were the same as for extracellular enzyme assays and were described by 
Wenham et al. (1979). Activities are expressed as $\mu \mathrm{g}$ glucan or fructan formed $\mathrm{h}^{-1}$ (ml suspension) ${ }^{-1}$. Chemical determinations were as described by Wenham et al. (1979).

Cariogenicity of $S$. mutans in pathogen-free rats. Albino rats were bred specifically pathogen-free in the Animal Breeding Unit, ICI Pharmaceuticals Division, Alderley Edge, Cheshire, according to category 4 of the Medical Research Council accreditation scheme. Pups from seven litters of six were distributed into pairs of similar weight when $20 \mathrm{~d}$ old. Bacteria from a freeze-dried culture were propagated on blood agar plus $1 \%(\mathrm{w} / \mathrm{v})$ glucose and transferred to $30 \mathrm{ml}$ brain heart infusion broth supplemented with $1 \%(\mathrm{w} / \mathrm{v})$ glucose. After $16 \mathrm{~h}$ at $37^{\circ} \mathrm{C}$, cells were harvested by centrifugation for $5 \mathrm{~min}$ at $3000 \mathrm{~g}$ and resuspended in $30 \mathrm{ml}$ sterile distilled water. The absorbance at $650 \mathrm{~nm}$ of each suspension was adjusted to 1.0 with sterile water and rats were inoculated with 0.2 $\mathrm{ml}$ via the tip of a blunt needle attached to a syringe. This inoculation procedure was repeated with fresh cultures of each strain for each of the following $4 \mathrm{~d}$. In addition, $25 \mathrm{ml}$ of the bacterial suspension was added to 11 of sterile tap water and used as drinking water for the first $5 \mathrm{~d}$ of the study. The cariogenic diet containing $66 \%(w / w)$ icing sugar, $32 \%(\mathrm{w} / \mathrm{w})$ skimmed milk powder and $2 \%(\mathrm{w} / \mathrm{w})$ liver extract was available ad libitum.

Cross-infection was reduced by keeping the same food and water containers in each cage throughout the study. Three cages containing uninfected rats were interspersed between cages of infected rats: if there had been extensive transfer of any of the test strains of $S$. mutans to other groups of rats, these uninfected rats would also become contaminated early in the trial and the caries score would be comparable to that of other groups. The caries score of this group therefore provides an indication of the extent of cross-contamination between cages.

The establishment of $S$. mutans was confirmed by taking oral swabs from two rats in each group 2 weeks after the first inoculation. A sterile, moistened swab was passed over the molar teeth and placed in $10 \mathrm{ml}$ of $0.9 \%(\mathrm{w} / \mathrm{v})$ saline. The swab was agitated in the saline on a vortex mixer. Duplicate $0.1 \mathrm{ml}$ samples of a $10^{-2}$ dilution were spread on mitis-salivarius agar and growth was recorded after $48 \mathrm{~h}$ at $37^{\circ} \mathrm{C}$. Many (20 to 500) colonies of $S$. mutans were observed on plates infected with samples from every rat exposed to the test $S$. mutans strains. It was impossible, however, to obtain quantitative estimates of the relative numbers of each $S$. mutans strain on the rats' teeth. No $S$. mutans colonies were obtained from samples taken before the rats were infected or from the uninfected control group of rats during the following $14 \mathrm{~d}$. Specifically pathogen-free rats therefore provide an adequate model for cariogenicity assays despite the preference by some research workers for gnotobiotic rats.

Rats were killed 4 weeks after the first inoculation. The heads were autoclaved, defleshed and the lower jaws were stored in alcohol prior to scoring for smooth surface caries by the following modification of the method of Keyes (1958). A low-power binocular microscope was used to score the extent of a lesion in one plane. Only lesions which had destroyed the surface integrity of the enamel and penetrated the dentine were recorded. The number of molars with lesions was first recorded. The number of carious areas was then assessed by dividing the buccal and lingual surfaces of the first molars (which were the largest) into three equal areas and of the second and third molars into two areas and then recording the number of areas with lesions. The smooth surface caries score was determined by assessing out of three the extent of the lesion in each of these areas. The maximum possible scores for the first or second and third molars are 18 and 12, respectively; the maximum possible score for an entire mandible is 84 .

\section{RESULTS}

\section{Rates of glucosyltransferase and fructosyltransferase synthesis by different strains of S. mutans}

Various strains of $S$. mutans were grown in continuous culture with either a limited supply or an excess of glucose, and extracellular and cell-associated glucosyl- and fructosyltransferase activities were determined (Tables 1 and 2).

Mutansucrase was extremely active in cultures of C67-1, the serotype $d$ strain $\mathrm{K} 1$ and the two serotype $c$ strains which had recently been isolated from carious dentine (3209 and 3450). Although little or no mutansucrase was detected in cultures of strains Ingbritt or C67-25, dextransucrase activity was readily detected. With the exception of the noncariogenic mutant C67-25, both dextransucrase and mutansucrase were more active in the extracellular fluid from cultures grown with excess glucose than in glucose-limited cultures. The concentrations of acid-precipitable protein in culture supernatants were in the range 80-100 $\mu \mathrm{g} \mathrm{ml}^{-1}$ and $150-200 \mu \mathrm{g} \mathrm{ml}^{-1}$ for cultures grown with a limited supply or excess glucose, respectively. The higher extracellular glucosyltransferase activities during growth of strains C67-1, Ingbritt and 3209 with excess glucose were therefore the result of a higher specific rate of enzyme synthesis rather than due to a constant rate of enzyme synthesis by a more dense culture. The same conclusion applies to the dextransucrase activity of strain 3450 . 
Table 1. Extracellular glucosyl- and fructosyltransferase activities of various strains of $S$. mutans after growth in continuous culture

Bacteria were grown in continuous culture at a dilution rate of $0.12 \mathrm{~h}^{-1}$ with either a limited supply $\left(6 \mathrm{~g} \mathrm{l}^{-1}\right)$ or an excess $\left(36 \mathrm{~g} \mathrm{l}^{-1}\right)$ of glucose and were sedimented by centrifugation. The clarified culture supernatant was used for enzyme assays. Each experiment was repeated with at least two, and in some cases from up to six, independent cultures which gave essentially identical results. Activities are expressed as $\mu \mathrm{g}$ glucose or fructose from sucrose polymerized $\mathrm{h}^{-1}(\mathrm{ml} \text { culture supernatant })^{-1}$.

\begin{tabular}{|c|c|c|c|c|c|c|}
\hline Strain & $\begin{array}{l}\text { Glucose } \\
\text { in feed }\end{array}$ & $\begin{array}{l}\text { Dextran } \\
\text { in assay }\end{array}$ & $\begin{array}{l}\text { Cell density } \\
\qquad\left(\mathrm{g} \mathrm{l}^{-1}\right)\end{array}$ & Dextransucrase & Mutansucrase & Fructosyltransferase \\
\hline C67-1 & $\begin{array}{l}\text { Limiting } \\
\text { Excess }\end{array}$ & $\begin{array}{l}+ \\
- \\
+ \\
-\end{array}$ & 0.84 & $\begin{array}{r}260 \\
59 \\
1100 \\
690\end{array}$ & $\begin{array}{r}50 \\
46 \\
450 \\
590\end{array}$ & $\begin{array}{l}190 \\
180 \\
190 \\
180\end{array}$ \\
\hline$C 67-25$ & $\begin{array}{l}\text { Limiting } \\
\text { Excess }\end{array}$ & $\begin{array}{l}+ \\
- \\
+ \\
-\end{array}$ & $\begin{array}{l}0.83 \\
2.40\end{array}$ & $\begin{array}{r}240 \\
170 \\
140 \\
80\end{array}$ & $\begin{array}{l}<5 \\
<5 \\
<5 \\
<5\end{array}$ & $\begin{array}{r}190 \\
190 \\
90 \\
70\end{array}$ \\
\hline Ingbritt & $\begin{array}{l}\text { Limiting } \\
\text { Excess }\end{array}$ & $\begin{array}{l}+ \\
- \\
+ \\
-\end{array}$ & $\begin{array}{l}1.05 \\
2.15\end{array}$ & $\begin{array}{r}70 \\
40 \\
430 \\
40\end{array}$ & $\begin{array}{r}4 \\
4 \\
18 \\
18\end{array}$ & $\begin{array}{l}720 \\
770 \\
320 \\
250\end{array}$ \\
\hline 3209 & $\begin{array}{l}\text { Limiting } \\
\text { Excess }\end{array}$ & $\begin{array}{l}+ \\
- \\
+ \\
-\end{array}$ & $\begin{array}{l}0.86 \\
1.53\end{array}$ & $\begin{array}{r}150 \\
125 \\
2100 \\
250\end{array}$ & $\begin{array}{r}200 \\
165 \\
4200 \\
4450\end{array}$ & $\begin{array}{l}160 \\
190 \\
540 \\
240\end{array}$ \\
\hline 3450 & $\begin{array}{l}\text { Limiting } \\
\text { Excess }\end{array}$ & $\begin{array}{l}+ \\
- \\
+ \\
-\end{array}$ & $\begin{array}{l}0.75 \\
2.30\end{array}$ & $\begin{array}{l}270 \\
135 \\
720 \\
220\end{array}$ & $\begin{array}{r}79 \\
83 \\
160 \\
290\end{array}$ & $\begin{array}{r}380 \\
320 \\
77 \\
75\end{array}$ \\
\hline K 1 & $\begin{array}{l}\text { Limiting } \\
\text { Excess }\end{array}$ & $\begin{array}{l}+ \\
- \\
+ \\
-\end{array}$ & $\begin{array}{l}0.80 \\
1.50\end{array}$ & $\begin{array}{r}170 \\
40 \\
200 \\
<40\end{array}$ & $\begin{array}{l}280 \\
270 \\
540 \\
490\end{array}$ & $\begin{array}{l}<10 \\
<10 \\
<10 \\
<10\end{array}$ \\
\hline
\end{tabular}

Glucosyltransferase synthesis by these serotype $c$ strains is not, therefore, regulated by catabolite repression (see Carlsson \& Elander, 1973; Ellwood \& Hunter, 1976). Dextran almost invariably stimulated the rate of soluble glucan synthesis and the dextransucrase activities of Ingbritt and $\mathrm{K} 1$ were totally dextran-dependent.

Fructosyltransferase was extremely active in the extracellular fluid from cultures of serotype $c$ strains but was not detected with the serotype $d$ strain, K1 (Table 1). Small quantities of insoluble fructan were formed with the culture fluid from strains 3450 and 3209 but this was less than $10 \%$ of the insoluble glucan formed and it might therefore be water-soluble fructan fortuitously trapped in the insoluble glucan matrix.

Cell-associated glucosyltransferase activities were detected with all of the strains examined (Table 2) but they were normally less, or far less, active than the corresponding extracellular enzymes. The glucosyltransferase activity in the extracellular fluid therefore provides a reliable indication of the relative quantities of enzyme formed by different strains (see also Janda \& Kuramitsu, 1976). The failure of dextran to stimulate the cell-associated activity (except when strain 3209 was grown with excess glucose) is consistent with the role postulated for dextran in binding glucosyltransferase to the cell surface. Small quantities of dextran may have been formed from traces of sucrose which contaminates the components of complex media.

\section{Colonization of S. mutans on nichrome wires}

The ability of cultures of $S$. mutans to colonize smooth, hard surfaces was investigated by assessing the quantity of bacteria bound to the surface of a nichrome wire suspended for $2 \mathrm{~d}$ 
Table 2. Cell-associated glucosyl-and fructosyltransferase activities of various strains of $S$. mutans after growth in continuous culture

Bacteria were harvested by centrifugation, washed with $0.1 \mathrm{M}$-sodium acetate $\mathrm{pH} 6.0$ and resuspended in acetate buffer to the same turbidity as in the original culture. Other details are as for Table 1. Activities are expressed as $\mu \mathrm{g}$ glucan or fructan formed $\mathrm{h}^{-1}$ (ml suspension) ${ }^{-1}$.

\begin{tabular}{|c|c|c|c|c|c|}
\hline Strain & $\begin{array}{l}\text { Glucose } \\
\text { in feed }\end{array}$ & $\begin{array}{l}\text { Dextran } \\
\text { in assay }\end{array}$ & $\begin{array}{l}\text { Cell density } \\
\qquad\left(\mathrm{g} \mathrm{l}^{-1}\right)\end{array}$ & Glucosyltransferase & Fructosyltransferase \\
\hline C67-1 & $\begin{array}{l}\text { Limiting } \\
\text { Excess }\end{array}$ & $\begin{array}{l}+ \\
- \\
+ \\
-\end{array}$ & $\begin{array}{l}0.84 \\
2.50\end{array}$ & $\begin{array}{r}65 \\
55 \\
140 \\
160\end{array}$ & $\begin{array}{l}20 \\
20 \\
95 \\
85\end{array}$ \\
\hline C67-25 & $\begin{array}{l}\text { Limiting } \\
\text { Excess }\end{array}$ & $\begin{array}{l}+ \\
- \\
+ \\
-\end{array}$ & $\begin{array}{l}0.83 \\
2.40\end{array}$ & $\begin{array}{c}\text { ND } \\
40 \\
\text { ND } \\
140\end{array}$ & $\begin{array}{r}40 \\
30 \\
120 \\
85\end{array}$ \\
\hline Ingbritt & Limiting & + & 1.05 & $\begin{array}{r}\text { ND } \\
77\end{array}$ & $\begin{array}{c}\text { ND } \\
80\end{array}$ \\
\hline & Excess & + & $2 \cdot 15$ & $\begin{array}{c}\text { ND } \\
65\end{array}$ & $\begin{array}{l}\text { ND } \\
140\end{array}$ \\
\hline 3209 & $\begin{array}{l}\text { Limiting } \\
\text { Excess }\end{array}$ & $\begin{array}{l}+ \\
- \\
+ \\
-\end{array}$ & $\begin{array}{l}0.86 \\
1.53\end{array}$ & $\begin{array}{r}100 \\
140 \\
115 \\
35\end{array}$ & $\begin{array}{r}140 \\
130 \\
105 \\
40\end{array}$ \\
\hline 3450 & $\begin{array}{l}\text { Limiting } \\
\text { Excess }\end{array}$ & $\begin{array}{l}+ \\
- \\
+ \\
-\end{array}$ & $\begin{array}{l}0.75 \\
2.30\end{array}$ & $\begin{array}{l}44 \\
43 \\
77 \\
52\end{array}$ & $\begin{array}{l}75 \\
72 \\
22 \\
49\end{array}$ \\
\hline \multirow[t]{2}{*}{ K 1} & Limiting & + & 0.80 & $\begin{array}{l}\text { ND } \\
155\end{array}$ & $\begin{array}{c}\text { ND } \\
50\end{array}$ \\
\hline & Excess & + & $1 \cdot 50$ & $\begin{array}{l}\text { ND } \\
210\end{array}$ & $\begin{array}{c}\text { ND } \\
80\end{array}$ \\
\hline
\end{tabular}

in a batch culture growing with glucose or sucrose (McCabe et al., 1967). Bacteria only formed large clumps on wires from cultures of strains 3209, K1 or C67-1 growing with sucrose (Fig. 1). The fluid around these wires was less turbid than the bulk culture. In contrast, strains C67-25 and Ingbritt formed clumps in the sucrose medium but did not adhere significantly to the wires (Fig. 1). These experiments demonstrated that sucrose enhances the ability of some but not all strains of $S$. mutans to colonize a smooth hard surface and to be retained on the wire during agitation and washing procedures.

\section{Comparison of the cariogenicity of different strains in rats}

Five of the strains which had been grown in continuous culture were used to determine whether there is a correlation between dextransucrase, mutansucrase or fructosyltransferase activities in such cultures and their cariogenicity in pathogen-free rats. Rats were orally infected with the organisms and fed a sucrose-rich diet. Strain D282, known to be cariogenic in rats, was included as a positive control, and uninfected rats provided a negative control. After 4 weeks, the mandibular jaw was scored for smooth surface caries on both the buccal and lingual surfaces of each of the six molars in each rat. The weight gain of each rat over the 4 weeks was measured and values for individuals within each group were comparable. Differences in caries scores between groups were not, therefore, the result of the consumption of more or less food. The total caries score, the total number of carious areas and the total number of carious molars were determined (Table 3 ).

Due to the nature and the absolute values of the data, a non-parametric statistical test was applied (Mann \& Whitney, 1947). There were no significant differences at the $95 \%$ 


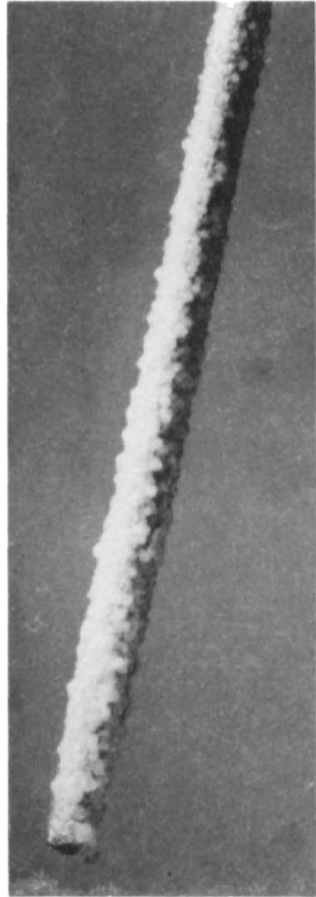

C67-1

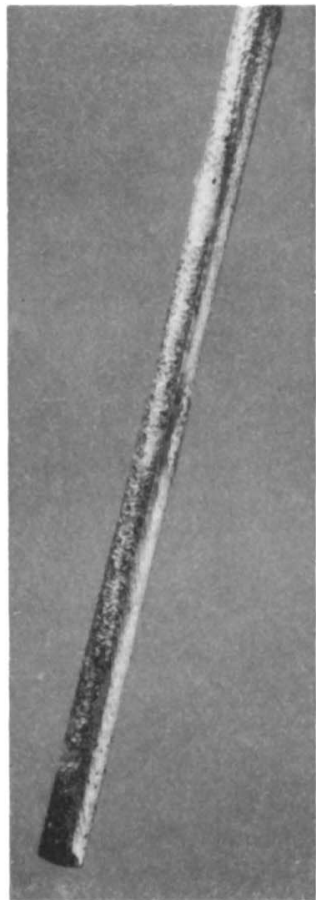

C67-25

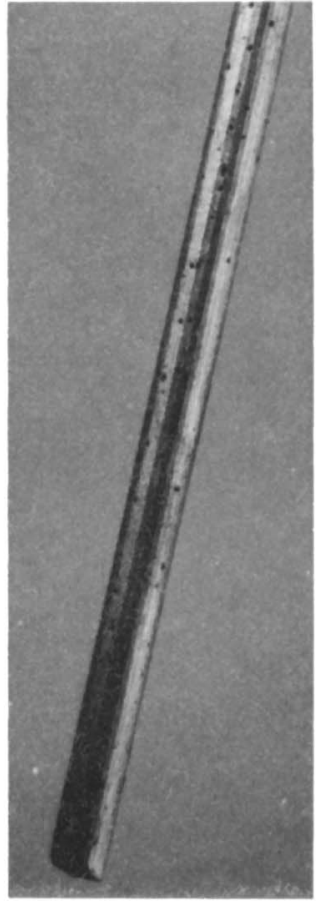

Ingbritt

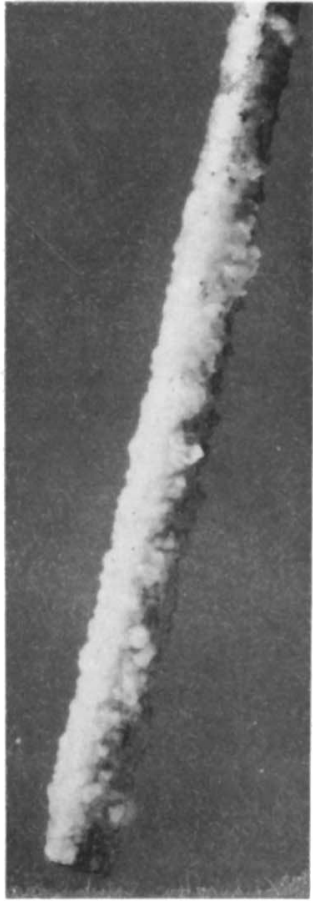

$\mathrm{K} 1$

Fig. 1. Adherence of $S$. mutans strains to a sterile nichrome wire. A sterile nichrome wire was inserted into a freshly inoculated $5 \mathrm{ml}$ culture of brain heart infusion broth containing sucrose. After $24 \mathrm{~h}$ the wire was transferred to a second tube of sterile broth and photographed after a further $24 \mathrm{~h}$.

\section{Table 3. Relative cariogenicities of six strains of S. mutans in pathogen-free rats}

Groups of six rats were orally infected and fed a cariogenic diet rich in sucrose. After $28 \mathrm{~d}$ the mandibles were scored for smooth surface caries (see Methods). Values are expressed as the mean for the six rats \pm standard error of the mean.

\begin{tabular}{lcrr}
\multicolumn{1}{c}{ Strain } & Carious molars & Carious areas & Caries score \\
Uninfected control & $0.5 \pm 0.2$ & $1.0 \pm 0.4$ & $1.2 \pm 0.4$ \\
D282 & $4.0 \pm 0.5$ & $11.1 \pm 2.2$ & $15.5 \pm 3.7$ \\
Ingbritt & $1.5 \pm 0.4$ & $2.5 \pm 0.8$ & $2.5 \pm 0.8$ \\
3209 & $3.8 \pm 0.7$ & $11.7 \pm 3.2$ & $19.2 \pm 6.5$ \\
C67-1 & $3.2 \pm 0.6$ & $7.8 \pm 1.9$ & $9.2 \pm 2.3$ \\
C67-25 & $1.0 \pm 0.5$ & $1.8 \pm 0.9$ & $1.8 \pm 0.9$ \\
K1 & $4.7 \pm 0.4$ & $14.5 \pm 2.6$ & $22.0 \pm 5.3$
\end{tabular}

confidence level in caries scores between rats which had been infected with strains $K 1,3209$, D282 or C67-1, all of which were highly cariogenic. Similarly, there were no significant differences between the caries incidence in groups infected with Ingbritt, C67-25 or in the uninfected control group. However, there was a highly significant difference in cariogenicity between strains $\mathrm{K} 1,3209, \mathrm{D} 282$ or $\mathrm{C67}-1$ and strains Ingbritt or C67-25. Identical conclusions were obtained from the statistical analysis of results from all three methods used to assess the incidence of caries.

\section{DISCUSSION}

The many factors known to influence the induction of dental caries include the age and susceptibility of the host, the diet (especially the availability of sucrose) and the oral flora. There is also substantial evidence that some strains of $S$. mutans are especially active in 
inducing smooth surface caries in man and rodents (Krasse et al., 1967; Loesche et al., 1975; Michalek et al., 1975). Essential steps in the disease process are the initial adherence of bacteria to a clean or saliva-coated tooth surface, growth of bacteria to form dental plaque and modification of the soft initial plaque to form a sticky, impermeable matrix within which acidic fermentation products accumulate. Mutan is an important structural component of this impermeable matrix, so the mutansucrase activity secreted by a strain might be a major determinant of its cariogenicity and its ability to form clumps on a smooth hard surface.

No strain-specific differences were detected in the growth rates, rates of glucose, fructose or sucrose fermentation or in the identity of the fermentation products of any of the strains used (Wenham et al., 1979; Wenham, 1979). Furthermore, no significant differences have been detected in the initial rate of adherence of these strains to hydroxyapatite beads (Adshead, Davies and Cole, unpublished) or in their cell-associated glucosyltransferase activities (Table 2). Differences in the cariogenicity of these strains were probably due to subsequent, sucrose-dependent steps in the colonization process, such as differences in the rate of insoluble glucan synthesis from sucrose.

Glucosyltransferase from bacteria growing with sucrose is first excreted into the extracellular fluid where it catalyses the synthesis of glucans which then bind the enzymes to the bacterial surface (Janda \& Kuramitsu, 1976). Subsequently, little glucosyltransferase activity can be detected, presumably because it is inaccessible to its substrate. It is therefore impossible to determine the rate of mutansucrase synthesis in the rat mouth during the cariogenicity experiments. Similarly, during growth in continuous culture with excess sucrose, glucans formed in the culture fluid promote adhesion of bacteria to each other and to surfaces of the fermenter, so steady-state growth cannot be achieved. To avoid these difficulties, we first established, as far as was possible, that rates of glucosyltransferase synthesis were similar during growth with glucose, fructose, sucrose or a mixture of glucose and fructose (Wenham et al., 1979; Wenham, 1979). Glucose was therefore used for continuous culture experiments in order to determine relative rates of glucosyltransferase synthesis by the different strains. Furthermore, there is now extensive evidence that the extracellular activity of glucosyltransferase correlates closely with the quantity of glucosyltransferase protein(s) synthesized during growth with glucose, but not during growth with sucrose (Wenham et al., 1979; Newman et al., 1980; Asem, Kenney \& Cole, unpublished).

In view of the role postulated for insoluble glucan in the development of smooth surface caries, it was at first surprising that the Ingbritt strain, which was originally isolated from a carious lesion (Krasse, 1966), produced little mutansucrase activity (Wenham et al., 1979). However, although this strain could readily be isolated from rat teeth 2 weeks after the initial infection, these rats developed significantly fewer lesions than those infected with four other strains of S. mutans. Although Ellwood et al. (1976) have documented differences in extracellular polysaccharides produced by cultures of the Ingbritt strain obtained from different laboratories, identical results were obtained from continuous culture experiments with Ingbritt cultures received from J. M. Hardie or D. C. Ellwood (Wenham et al., 1979). Presumably, both cultures are non-cariogenic derivatives of the original isolate which has been sub-cultured repeatedly on laboratory media. Significantly, the two recent clinical isolates were both prolific sources of mutansucrase activity, and strain 3209 was both cariogenic and formed dense deposits on nichrome wires. These results illustrate the importance of checking the cariogenicity of strains used before factors involved in the disease process are investigated.

Strains C67-1 and C67-25 were included in this study because it had already been shown that C67-25, unlike its parent, was neither cariogenic nor able to synthesize insoluble glucans from sucrose (De Stoppelaar et al., 1971, 1973). These results were readily confirmed, but were the only differences detected between the two strains (Table 1). The serotype $d$ strain, $\mathrm{K} 1$, produced no fructosyltransferase and little dextransucrase activity, but was both cariogenic and able to stick to nichrome wires. 
We conclude that previous confusion in the literature about the role, if any, of glucosyltransferase in the disease process has largely resulted from the failure of many authors to distinguish between the dextransucrase, mutansucrase and fructosyltransferase activities secreted by the strains under investigation. Incorrect conclusions have also been drawn from experiments in which enzymes have been assayed under sub-optimal conditions. When these pit-falls are avoided, it is apparent that strains of $S$. mutans with a high mutansucrase activity are significantly more cariogenic than those which secrete little mutansucrase activity. There are no similar correlations between the total glucosyltransferase activity, the dextransucrase activity or the fructosyltransferase activity and cariogenicity.

We are grateful to Drs R. R. B. Russell and M. Winter for extensive collaboration and to Miss K. Miller for excellent technical assistance during the cariogenicity trials. D.G.W. was supported by a Science Research Council Cooperative Award in Science and Engineering sponsored by Imperial Chemical Industries Ltd, Pharmaceuticals Division. Macclesfield. Cheshire.

\section{REFERENCES}

Baird, J. K., Longyear, V. M. C. \& Ellwood, D. C. (1973). Water insoluble and soluble glucans produced by extracellular glycosyltransferases from Streptococcus mutans. Microbios 8, 143-150.

CARLSSON, J. \& Elander, B. (1973). Regulation of dextransucrase formation by Streptococcus sanguis. Caries Research 7, 89-101.

CARlsson, J. \& Griffith. C. J. (1974). Fermentation products and bacterial yields in glucose-limited and nitrogen-limited cultures of streptococci. Archives of Oral Biology 19, 1105-1109.

De Stoppelaar, J. D., Konig, K. G., Plasschaert, A. J. M. \& VAN DER HOEven, J. S. (1971). Decreased cariogenicity of a mutant of Streptococcus mutans. Archives of Oral Biology 16. 971-975.

De Stoppelaar. J. D., Huis in 't Veld, J. H. J. \& Zuurveen, R. (1973). Properties of a strain of Strep. mutans and its non-cariogenic mutant. Journal of Dental Research 52, 171 (IADR abstract 451).

Dummer, P. M. H. \& Green, R. M. (1980). A comparison of the ability of strains of streptococci to form dental plaque-like deposits in vitro with their cariogenicity in gnotobiotic rats. Archices of Oral Biology 25. 245-249.

Elliwood. D. C. \& Hunter. J. R. (1976). The mouth as a chemostat. In Continuous Cultures: Application and New Fields. Proceedings of the 6th International Symposium on Continuous Culture of Microorganisms. pp. 270-282. Edited by A. C. R. Dean. D. C. Ellwood, C. G. J. Evans \& J. Melling. Chichester: Ellis Horwood.

Ellwood. D. C.. Baird. J. K.. Hunter. J. R. \& LONGYEAR. V. M. C. (1976). Variations in surface polymers of Streptococcus mutans. Journal of Dental Research 55, C42-C49.

Freedman. M. L. \& TANZer. J. M. (1974). Dissociation of plaque formation from glucan-induced agglutination in mutants of Streptococcus mutans. Infection and Immunity 10, 189-196.

GEDDES. D. A. M. (1975). Acids produced by human dental plaque metabolism in situ. Caries Research 9. 98-109.
Guggenheim, B., Regolati, B. \& MuhlemanN, H. R. (1972). Caries and plaque inhibition by mutanase in rats. Caries Research 6, 289-297.

Guggenheim, B., Regolati, B., Schmidt, R. \& MunlemanN, H. R. (1980). Effects of the topical application of mutanase on rat caries. Caries Research 14, 128-135.

Hamilton, I. R., Phipps, P. J. \& Ellwood, D. C. (1979). Effect of growth rate and glucose concentration on the biochemical properties of Streptococcus mutans Ingbritt in continuous culture. Infection and Immunity 26, 861-869.

VAN DER HOEVEN, J. S. (1976). Carbohydrate metabolism of Streptococcus mutans in dental plaque in gnotobiotic rats. Archives of Oral Biology 21, 431-433.

Hojo, S., Higuchi, M. \& Araya, S. (1976). Glucan inhibition of diffusion in plaque. Journal of Dental Research 55, 169.

Janda, W. M. \& Kuramitsu, H. K. (1976). Regulation of extracellular glucosyltransferase production and the relationship between extracellular and cell-associated activities in Streptococcus mutans. Infection and Immunity 14, 191-202.

KeYES, P. H. (1958). Dental caries in the molar teeth of rats II. Method for diagnosing and scoring several types of lesion simultaneously. Journal of Dental Research 37, 1088-1099.

KogA, T. \& INOUE, M. (1978). Cellular adherence. glucosyltransferase adsorption and glucan synthesis of Streptococcus mutans AHT mutants. Infection and Immunity 19, 402-410.

KRASSE, B. (1966). Human streptococci and experimental caries in hamsters. Archives of Oral Biology' 11, 429-436.

Krasse, B., Edwardsson, S., Svensson, I. \& Trell, L. (1967). Implantation of caries inducing streptococci in the human oral cavity. Archives of Oral Biology 12, 231-236.

Loesche, W. J., Rowan, J., Straffon, L. H. \& Loos, P. J. (1975). Association of Streptococcus mutans with human dental decay. Infection and Immunity $11,1252-1260$.

ManN, H. B. \& Whitney. D. R. (1947). On a test of 
whether one of two random variables is stochastically larger than the other. Annals of Mathematical Statistics 18, 50-60.

MCCABE, R. M., Keyes, P. H. \& Howell, A. (1967).

An in vitro method for assessing the plaque-forming ability of oral bacteria. Archives of Oral Biology 12, 1653-1656.

MichaleK, S. M., McGhee, J. R. \& Navia, J. M. (1975). Virulence of Streptococcus mutans: a sensitive method for evaluating cariogenicity in young gnotobiotic rats. Infection and Immunity 12, 69-75.

Newman, B. M., White, P., Mohan, S. B. \& Cole, J. A. (1980). Effect of dextran and ammonium sulphate on the reaction catalysed by a glucosyltransferase complex from Streptococcus mutans. Journal of General Microbiology 118, 353-366.

SChachtele, C. F., Germaine, G. R. \& Harlander, S. K. (1975). Production of elevated levels of dextransucrase by a mutant of Streptococcus mutans. Infection and Immunity 12, 934-937.
Shklair, I. L. \& KeENe, H. J. (1974). A biochemical scheme for the separation of the five varieties of Streptococcus mutans. Archives of Oral Biology 19, 1079-1081.

Smith, D. J., Taubman, M. A. \& Ebersole, J. L. (1979). Effect of oral administration of glucosyltransferase antigens on experimental dental caries. Infection and Immunity 26, 82-89.

TANZer, J. M., Freedman, M. L., Fitzgerald, R. J. \& LARSEN, R. H. (1974). Diminished virulence of glucan synthesis-defective mutants of Streptococcus mutans. Infection and Immunity 10, 197-203.

WENHAM, D. G. (1979). The regulation of glucosyltransferase synthesis by Streptococcus mutans. Ph.D. thesis, University of Birmingham, U.K.

Wenham, D. G., Hennessey, T. D. \& Cole, J. A. (1979). Regulation of glucosyl- and fructosyltransferase synthesis by continuous cultures of Streptococcus mutans. Journal of General Microbiology 114, 117-124. 